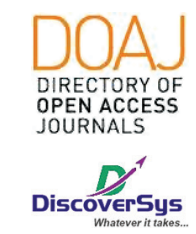

Published by DiscoverSys

\title{
Sikap mahasiswa Program Studi Sarjana Kedokteran dan Profesi Dokter angkatan 2016 Fakultas Kedokteran Universitas Udayana terhadap peran media sosial sebagai alternatif small group discussion secara online
}

\author{
Ida Bagus Made Mahendra Wisma, ${ }^{1 *}$ Putu Ayu Asri Damayanti, ${ }^{2}$ Ni Putu Wardani ${ }^{2}$
}

\section{ABSTRACT}

Background: The rapid development of information and communication technology provides an alternative in disseminating knowledge, especially accessing information in the field of education. Increasing access to information through social media can develop cognitive power in student groups, such as through discussion learning methods based on Small Group Discuccion (SGD) at the Faculty of Medicine, Udayana University.

Aim: To evaluate the attitude of students batch 2016 Medical Faculty and Doctor Professional Study Program (PSSKPD) Faculty of Medicine of Udayana University towards the role of social media as an alternative to online SGD

Method: This study was an observational study using a cross sectional descriptive design of the batch 2016 PSSKPD students of the Faculty of Medicine, Udayana University in the period AugustNovember 2019.

Result and Conclusion: The most commonly used social media by PSSKPD students batch 2016 at the Faculty of Medicine of Udayana University in carrying out SGD was social media LINE (83.5\%). The description related to knowledge about the role and benefits of social media is $84.4 \%$. The description of students' attitude towards social media-based SGD has a high positive value of $97.9 \%$. The description of students' attitudes towards the amount of information obtained through SGD based on social media namely $89.6 \%$ agreed and $20.8 \%$ strongly agreed. The role of social media as an alternative to SGD online greatly helps students learn. understanding the topic of discussion as well as interacting, arguing, and add insights.

Keywords: student attitude, social media, online SGD

Cite This Article: Wisma, I.B.M.M., Damayanti, P.A.A., Wardani, N.P. 2020. Sikap mahasiswa Program Studi Sarjana Kedokteran dan Profesi Dokter angkatan 2016 Fakultas Kedokteran Universitas Udayana terhadap peran media sosial sebagai alternatif small group discussion secara online. Intisari Sains Medis 11(2): 738-744. D0I: 10.15562/ism.v11i2.681

\section{ABSTRAK}

Latar Belakang: Perkembangan teknologi informasi dan komunikasi yang sangat pesat memberikan alternatif dalam menyebarluaskan

${ }^{1}$ Program Studi Sarjana Kedokteran dan Profesi Dokter, Fakultas Kedokteran Universitas Udayana, Denpasar, Bali ${ }^{2}$ Department of Medical Education Fakultas Kedokteran, Universitas Udayana Denpasar, Bali

${ }^{*}$ Correspondence to:

Ida Bagus Made Mahendra Wisma, Program Studi Sarjana Kedokteran dan Profesi Dokter, Fakultas Kedokteran Universitas Udayana, Denpasar, Bali gusmahendra_5@yahoo.com

Diterima: 30-12-2019

Disetujui: 26-06-2020

Diterbitkan: 01-08-2020
PSSKPD angkatan 2016 Fakultas Kedokteran Universitas Udayana periode Agustus-November 2019.

Hasil dan Simpulan: Media sosial yang paling sering digunakan oleh mahasiswa PSSKPD angkatan 2016 Fakultas Kedokteran Universitas Udayana dalam melaksanakan SGD adalah media sosial LINE (83,5\%). Gambaran terkait pengetahuan mengenai peran dan manfaat media sosial adalah sebesar 84,4\%. Gambaran sikap pernyataan mahasiswa terhadap SGD berbasis media sosial memiliki nilai positif yang tinggi sebesar 97,9\%. Gambaran sikap mahasiswa terhadap besarnya informasi yang didapatkan melalui SGD berbasis media sosial yakni 89,6\% menyatakan setuju dan 20,8\% sangat setuju. Peran media sosial sebagai alternatif SGD online sangat membantu mahasiswa belajar. memahami topik diskusi serta, berinteraksi, berargumentasi, serta saling menambah wawasan. 


\section{PENDAHULUAN}

Perkembangan teknologi informasi dan komunikasi yang sangat pesat memberikan langkah alternatif dalam menyebarluaskan ilmu pengetahuan serta mempermudah mengakses informasi. Media sosial merupakan akses komunikasi online secara sosial yang ditemukan sejak tahun 1978 hingga terus mengalami proses pembaharuan. Sampai saat ini, media sosial adalah salah satu metode kunci pembelajaran yang memiliki berbagai keunggulan berupa kemudahan mengakses data, menyimpan data, beragumentasi secara langsung, telepon, video call, rekaman, dan foto. Media sosial dapat memacu daya kognitif mahasiswa untuk memecahkan berbagai permasalahan di Small Group Discussion (SGD). ${ }^{1}$

SGD merupakan salah satu metode pembelajaran yang dilakukan di Fakultas Kedokteran Universitas Udayana yaitu metode pembelajaran dalam bentuk diskusi yang diikuti oleh mahasiswa dengan jumlah anggota antara 10 sampai 13 orang dengan durasi pelaksanaan SGD selama 100 menit. Fakultas Kedokteran Universitas Udayana menerapkan sistem pembelajaran student centered yaitu pembelajaran yang berpusat langsung kepada mahasiswa itu sendiri. Program Studi Sarjana Kedokteran dan Profesi Dokter (PSSKPD) sudah menerapakan konsep problem based learning (PBL) dalam melaksanakan kurikulum sejak semester 1 pada blok studium generale. Beberapa proses pembelajaran di Fakultas Kedokteran meliputi lecture, SGD, independent learning, dan plenary.

SGD selain memiliki keunggulan karena meningkatkan peran aktif mahasiswa juga memiliki berbagai kekurangan antara lain terbatasnya waktu dalam berkomunikasi, tempat, kesulitan mencari data, mengakses data, dan menyimpan data. ${ }^{2}$ SGD berbasis daring atau online dilaksanakan pertama kali pada blok community based practice yang dilaksanakan pada forum diskusi bernama E-learning. Selain berdiskusi melalui E-learning, mahasiswa diberikan pengayaan dengan batas waktu pengerjaan 4 jam serta difasilitasi langsung oleh pengempu blok. Pengempu blok akan menilai keaktifan mahasiswa dalam berinteraksi di forum tersebut. Kolaborasi pembelajaran maupun SGD berbasis daring dengan media sosial atau forum diskusi online menjadikan mahasiswa kedokteran memiliki alternatif dalam pelaksanaan SGD. SGD secara online dihrapkan dapat memenuhi fungsi mengakses data, menyimpan data, berkomunikasi dan dokumentasi secara optimal sehingga menciptakan proses pendidikan kedokteran yang dinamis. ${ }^{3}$ Sistem teknologi informasi dengan penerapan media sosial seperti LINE, Facebook, Twiter, Whatsapp dan sebagainya dapat dimanfaatkan sebagai media untuk SGD online. Penggunaan media sosial tersebut diharapkan menjadi peluang alternatif serta metode pembelajaran yang lebih fleksibel bagi mahasiswa. sehingga diharapkan terjadi peningkatan terhadap hasil pembelajaran. ${ }^{4}$

Berdasarkan pada pemaparan di atas, maka penelitian ini bertujuan untuk mengetahui lebih lanjut mengenai mengetahui sikap mahasiswa PSSKPD angkatan 2016 Fakultas Kedokteran Universitas Udayana terhadap peran media sosial sebagai alternatif SGD secara online.

\section{METODE}

Penelitian ini merupakan penelitian observasional yang menggunakan rancangan deskriptif potong lintang selama periode Agustus-November 2019. Penelitian ini bertujuan untuk mengetahui sikap mahasiswa terhadap peran media sosial sebagai alternatif SGD secara online dengan menggunakan kuesioner untuk mengumpulkan data. Penelitian ini dimulai dari proses perancangan tema, penyusunan proposal, pelaksanaan penelitian, pengumpulan, dan analisis data yang kemudian dikaji dan dibuat dalam bentuk laporan penelitian. Sampel diambil dengan menggunakan metode purposive sampling yaitu pengambilan sampel dengan mengetahui ciri-ciri atau sifat populasi yang sudah diketahui sebelumnya berdasarkan kriteria inklusi dan eksklusi. Adapun instrumen yang digunakan dalam penelitian yakni kuesioner sikap mahasiswa terhadap peran media sosial sebagai alternatif SGD secara online yang merupakan adaptasi dari Silaban dan Yanse, ${ }^{5,6}$ serta lembar persetujuan atau informed consent. Data yang didapat diolah secara manual, dianalisa secara deskriptif dan disajikan dalam bentuk tabel distribusi frekuensi. Setelah analisis selesai akan didapatkan hasil penelitian dan kemudian dapat ditemukan kesimpulan akhir.

\section{HASIL}

Dari total sampel yang diperoleh, hanya 96 sampel yang memenuhi kriteria inklusi dan eksklusi. Selanjutnya dilakukan analisis statitsik untuk melihat gambaran distribusi frekuensi responden berdasarkan jenis kelamin. Berdasarkan sajian pada Tabel 1 terlihat bahwa proporsi jenis kelamin tertinggi dijumpai pada responden berjenis kelamin perempuan dengan persentase lebih dari setengahnya.

Seluruh responden yang memenuhi kriteria penelitian, kemudian dilakukan analisis univariat terhadap variabel usia untuk melihat gambaran karakteristik sampel yang sebelumnya telah dilakukan uji normalitas dengan uji Kolmogrov-Smirnov 
Tabel 1 Karakteristik responden penelitian berdasarkan jenis kelamin

\begin{tabular}{lcc}
\hline Jenis Kelamin & Jumlah $(\boldsymbol{n}=\mathbf{9 6})$ & Persentase (\%) \\
\hline Laki-laki & 41 & $42,7 \%$ \\
Perempuan & 55 & $57,3 \%$ \\
Total & 96 & $100 \%$ \\
\hline
\end{tabular}

Tabel 2 Karakteristik responden penelitian berdasarkan usia

\begin{tabular}{lcc}
\hline Usia $(\boldsymbol{t} \boldsymbol{h})$ & Jumlah $(\boldsymbol{n}=\mathbf{9 6})$ & Persentase (\%) \\
\hline 19 & 4 & $4,2 \%$ \\
20 & 13 & $13,5 \%$ \\
21 & 63 & $65,6 \%$ \\
22 & 15 & $15,6 \%$ \\
23 & 1 & $1 \%$ \\
Total & 96 & $100 \%$ \\
\hline
\end{tabular}

Tabel 3 Jenis media sosial yang digunakan responden

\begin{tabular}{lccc}
\hline Media Sosial & Jumlah $(\boldsymbol{n})$ & Persentasea & Persentase* $^{*}$ \\
\hline LINE & 91 & $83,5 \%$ & $94,8 \%$ \\
Facebook & 1 & $0,9 \%$ & $1,0 \%$ \\
Whatssapp & 11 & $10,1 \%$ & $11,5 \%$ \\
Lain-lain & 6 & $5,5 \%$ & $6,3 \%$ \\
Total & 109 & $100 \%$ & $113,5 \%$ \\
\hline
\end{tabular}

Tabel 4 Karakteristik tingkat pengetahuan responden

\begin{tabular}{lcc}
\hline Tingkat Pengetahuan & Jumlah $(\boldsymbol{n}=\mathbf{9 6})$ & Persentase (\%) \\
\hline Baik & 81 & $84,4 \%$ \\
Kurang & 15 & $15,6 \%$ \\
Total & 96 & $100 \%$ \\
\hline
\end{tabular}

Tabel 5 Gambaran sikap mahasiswa dalam melakukan diskusi dan belajarmelalui SGD berbasis media sosialsecara online (pernyataan kuesioner 1 - 10)

\begin{tabular}{lcccc}
\hline Pernyataan & STS & TS & S & ST \\
\hline 1 & $1(1,0 \%)$ & $18(18,8 \%)$ & $52(54,2 \%)$ & $25(25 \%)$ \\
2 & $0(0 \%)$ & $21(21,9 \%)$ & $56(58,3 \%)$ & $19(19,8 \%)$ \\
3 & $1(1,0 \%)$ & $3(3,1 \%)$ & $76(79,2 \%)$ & $16(16,7 \%)$ \\
4 & $1(1,0 \%)$ & $4(4,2 \%)$ & $70(72,9 \%)$ & $21(21,9 \%)$ \\
5 & $2(2,1 \%)$ & $2(2,1 \%)$ & $69(71,9 \%)$ & $23(24 \%)$ \\
6 & $0(0 \%)$ & $2(2,1 \%)$ & $82(85,4 \%)$ & $12(12,5 \%)$ \\
7 & $1(1,0 \%)$ & $22(22,9 \%)$ & $66(66,8 \%)$ & $7(7,3 \%)$ \\
8 & $2(2,1 \%)$ & $25(26 \%)$ & $58(60 \%)$ & $11(11,5 \%)$ \\
9 & $1(1,0 \%)$ & $46(47,9 \%)$ & $41(42,7 \%)$ & $8(8,3 \%)$ \\
10 & $2(2,1 \%)$ & $47(49 \%)$ & $44(45,8 \%)$ & $3(3,1 \%)$ \\
Rata-rata (Mean) & & & & 2,9 \\
\hline
\end{tabular}

dengan hasil data yang tidak terdistribusi normal ( $\mathrm{p}<0,05$ ). Usia minimal pada penelitian ini adalah 19 tahun, sedangkan usia maksimum adalah 23 tahun. Median dari variabel usia adalah 21 tahun. Berdasarkan hasil yang disajikan pada Tabel 2 didapatkan bahwa kelompok usia 21 tahun merupakan kelompok usia dengan persentase terbanyak, yaitu lebih dari 50\%. Sedangkan kelompok usia dengan persentase paling kecil ditempati kelompok usia 23 tahun dengan persentase hanya $1 \%$. Gambaran karakteristik jenis media sosial yang digunakan responden dalam penelitian ini diukur menggunakan satu pertanyaan dalam kuesioner dengan bentuk multiple response atau dapat dijawab lebih dari satu. Analisis untuk mengetahui distribusi frekuensi media sosial dilakukan dengan menggunakan fungsi frekuensi multiple responses.

Pada Tabel 3 menunjukkan bahwa media sosial LINE merupakan jenis media sosial yang paling banyak digunakan oleh responden, yaitu berjumlah $91(83,5 \%)$ orang, kemudian diikuti oleh media sosial whatssapp sebanyak 11 orang $(10,1 \%)$. Media sosial Facebook tidak banyak digunakan oleh responden, yaitu hanya 1 orang $(0,9 \%)$ dari total 96 sampel, sedangkan 6 orang lainnya $(5,5 \%)$ merupakan pengguna media sosial lainnya, diluar kelompok media sosial yang dicantumkan pada tabel diatas. Tabel tersebut memperlihatkan persentase keseluruhan dan persentase kasus. Hasil tersebut menunjukkan bahwa media sosial LINE merupakan jenis media sosial yang memiliki persentase pengguna terbanyak berdasarkan jumlah sampel ataupun jumlah respon. Line merupakan media sosial yang memiliki banyak manfaat antara lain bisa berinteraksi secara masal lebih dari 100 orang dan kelebihan lainnya Line juga dapat menyimpan data, mengunduh data, mengirim data serta kelebihan yang dapat dirasakan secara maksimal oleh mahasiswa PSSKPD.

Tingkat pengetahuan responden dalam penelitian ini diukur dengan menggunakan 10 pertanyaan mengenai media sosial dengan poin $10 \%$ untuk satu pertanyaan. Pengelompokan skor tingkat pengetahuan adalah menggunakan titik potong $80 \%$ yang dibagi menjadi dua kategori, yaitu tingkat pengetahuan baik dan tingkat pengetahuan kurang. Sepuluh pertanyaan dalam kuesioner untuk mengukur tingkat pengetahuan responden telah dilakukan uji Cronbach's Alpha untuk mengetahui reliabilitas kuesioner. Hasil uji konsistensi internal pada pertanyaan mengenai pengetahuan, yaitu 0,138 yang menunjukkan reliabilitas yang baik dari kuesioner.

Hasil yang disajikan pada Tabel 4 menunjukkan bahwa pengelompokan tingkat pengetahuan dengan nilai titik potong adalah $80 \%$ menunjukkan 
Tabel 6 Gambaran sikap mahasiswa terhadapbesarnya informasi yang didapatkan melalui sgd berbasis media sosial (pernyataan kuesioner 11 - 15)

\begin{tabular}{lcccc}
\hline Pernyataan & STS & TS & S & ST \\
\hline 11 & $1(1,0 \%)$ & $36(37,5 \%)$ & $51(53,1 \%)$ & $8(8,3 \%)$ \\
12 & $0(0 \%)$ & $10(10,4 \%)$ & $66(68,8 \%)$ & $20(20,8 \%)$ \\
13 & $1(1,0 \%)$ & $37(38,5 \%)$ & $50(52,1 \%)$ & $8(8,3 \%)$ \\
14 & $1(1,0 \%)$ & $44(45,8 \%)$ & $41(42,7 \%)$ & $10(10,4 \%)$ \\
15 & $2(2,1 \%)$ & $32(33,3 \%)$ & $52(54,2 \%)$ & $10(10,4 \%)$ \\
Rata-rata (Mean) & & & & $\mathbf{2 , 8}$ \\
\hline
\end{tabular}

Tabel 7 Gambaran sikap mahasiswa terhadap seberapa besar mahasiswa menikmati diskusi melalui sgd berbasis media sosial (kuesioner 16 - 19)

\begin{tabular}{lcccc}
\hline Pernyataan & STS & TS & S & ST \\
\hline 16 & $0(0 \%)$ & $47(49 \%)$ & $41(42,7 \%)$ & $8(8,3 \%)$ \\
17 & $1(1 \%)$ & $6(6,3 \%)$ & $76(79,2 \%)$ & $13(13,5 \%)$ \\
18 & $0(0 \%)$ & $40(41,7 \%)$ & $46(47,9 \%)$ & $10(10,4 \%)$ \\
19 & $1(1 \%)$ & $3(3,1 \%)$ & $73(76 \%)$ & $19(19,8 \%)$ \\
Rata-rata (Mean) & & & & $\mathbf{2 , 8}$ \\
\hline
\end{tabular}

Tabel 8 Gambaran persepsi mahasiswa terhadap sgd berbasis media sosial

\begin{tabular}{lcccc}
\hline Pernyataan & STS & TS & S & ST \\
\hline 20 & $1(1,0 \%)$ & $55(57,3 \%)$ & $38(39,6 \%)$ & $2(2,1 \%)$ \\
21 & $2(2,11 \%)$ & $41(42,7 \%)$ & $49(51 \%)$ & $4(4,2 \%)$ \\
22 & $9(9,4 \%)$ & $70(72,9 \%)$ & $16(16,7 \%)$ & $1(1,0 \%)$ \\
23 & $9(9,4 \%)$ & $55(57,3 \%)$ & $31(32,3 \%)$ & $1(1,0 \%)$ \\
24 & $4(4,2 \%)$ & $55(57,3 \%)$ & $34(35,4 \%)$ & $3(3,1 \%)$ \\
25 & $6(6,3 \%)$ & $74(77,1 \%)$ & $16(16,7 \%)$ & $0(0 \%)$ \\
26 & $6(6,3 \%)$ & $48(50 \%)$ & $42(43,8 \%)$ & $0(0 \%)$ \\
27 & $1(1,0 \%)$ & $5(5,2 \%)$ & $80(83,3 \%)$ & $10(10,4 \%)$ \\
28 & $0(0 \%)$ & $7(7,3 \%)$ & $81(84,4 \%)$ & $8(8,3 \%)$ \\
Rata-rata (Mean) & & & & $\mathbf{2 , 7 6}$ \\
\hline
\end{tabular}

bahwa sebagian besar responden memiliki pengetahuan yang baik mengenai peran dan manfaat media sosial yang digunakan dalam kehidupan sehari-hari.

Sikap mahasiswa terhadap peran media sosial sebagai alternatif SGD secara online diukur dengan menggunakan kuesioner yang merupakan adaptasi dari kuesioner Silaban dan Yanse, ${ }^{5,6}$ Penelitian ini mempelajari 4 komponen sikap, yaitu 1) sikap mahasiswa terhadap SGD berbasis media sosial; 2) seberapa banyak mahasiswa belajar dengan SGD berbasis media social; 3) seberapa besar mahasiswa menikmati diskusi melalui SGD berbasis media sosial; 4) persepsi mahasiswa terhadap SGD berbasis media sosial. Kategori ini dilakukan dengan tujuan untuk memudahkan interpretasi data. Komponen sikap pertama dinilai dengan 10 pernyataan. Komponen kedua dinilai dengan 5 pernyataan. Komponen sikap ketiga dinilai dengan 4 pernyataan. Komponen sikap keempat dinilai dengan 7 pernyatan. Masingmasing pernyataan memiliki 2 kategori sikap yaitu sikap positif dan sikap negatif. Sikap positif adalah sikap yang menyatakan setuju dan sangat setuju terhadap pernyataan dengan skor 2,5-4. Sedangkan sikap negatif adalah sikap tidak setuju atau menolak pernyataan dengan skor 1-2,4. Setiap pernyataan memiliki 4 kategori jawaban yaitu sangat setuju (SS), setuju (S), tidak setuju (TS), dang sangat tidak setuju (STS). Keempat kategori jawaban ini memiliki skor masingmasing secara berurutan adalah $\mathrm{SS}=4, \mathrm{~S}=3, \mathrm{TS}=2$, STS $=1$. Pada analisa konsitensi internal, ditemukan koefisien Cronbach's Alpha masing-masing komponen secara berurutan adalah 0,720, 0,734, $0,739,0,806,0,828$. 
Berdasarkan hasil analisis yang ditunjukkan oleh Tabel 5, pernyataan ke-6 memiliki persentase positifyang paling tinggi. Dari $97,9 \%$ responden $(85,4 \%=$ setuju dan $12,5 \%=$ sangat setuju $)$ menyatakan sikap postif untuk berbagai informasi dan membantu teman lain memahami topik diskusi melalui SGD berbasis media sosial. Persentase positif kedua tertinggi adalah pernyataan ke- 3 dan ke-5. Pada pernyataan ke-3, dari 95,9\% responden $(79,2 \%=$ setuju dan $16,7 \%=$ sangat setuju $)$ menya takan sikap positif bahwa seorang mahasiswa dapat lebih mudah mengambil keputusan dan penyelesaian kasus mengenai topik diskusi dengan SGD berbasis media sosial. Pernyataan ke-5, dengan persentase yang sama dengan pernyataan ke-3 $(71,9 \%=$ setuju dan $24 \%=$ sangat setuju $)$, menyatakan sikap positif jika membantu teman diskusi untuk memahami topikmelalui SGD berbasis media sosial, juga membantu dirinya sendiri untuk belajar dan menambah wawasan.

Tabel 6 menyediakan data dari pernyataan kuesioner 11 - 15. Pernyataan ke-12 menunjukkan persentase setuju tertinggi. Sekitar 89,6\%, responden yang setuju sekitar $68,8 \%$ dan sangat setuju $20,8 \%$ terhadap pernyataan yang menunjukkan bahwa peran media sosial sebagai alternatif SGD berbasis online sangat membantu mahasiswa untuk memudahkan mereka belajar dan memahami topik diskusi. Persentase tertinggi kedua adalah pernyataan ke-15, dengan $54,2 \%$ responden menyatakan setuju dan $10,4 \%$ menyatakan sangat setuju terhadap peran SGD berbasis media sosial dalam membantu mengorganisasikan topik diskusi secara lebih baik dibandingkan SGD konvensional. Pada pernyataan ke-13, lebih dari 50\% responden menunjukkan sikap setuju dan sangat setuju terhadap peran media sosial sebagai alternatif SGD berbasis online untuk meningkatkan informasi dan pemahaman mengenai topik diskusi. Pada pernyataan ke-14, terdapat 41 orang $(42,7 \%)$ setuju dan 10 orang $(10,4 \%)$ sangat setuju bahwa SGD berbasis media sosial akan meningkatkan kebiasaan belajar responden.

Menurut hasil analisis pada data yang disediakan di 8 mengenai seberapa besar mahasiswa menikmati SGD berbasis media sosial, persentase tertinggi adalah pernyataan ke-19. Dari 100\% responden, $76 \%$ menyatakan setuju dan 19,8\% menyatakan sangat setuju jika mereka menikmati SGD berbasis media sosial karena merasa menjadi bagian dari kelompok diskusi. Persentase tertinggi kedua yang menunjukkan sikap positif adalah pernyataan ke- 17 . Terdapat $92,7 \%$ responden menunjukkan sikap positif $(79,2 \%$ setuju dan $13,5 \%$ sangat setuju) bahwa seluruh peserta diskusi mampu menghargai setiap pendapat dan argument yang diberikan selama diskusi berlangsung. Pada pernyataan ke-16, terdapat $42,7 \%$ responden setuju dan $8,3 \%$ responden sangat setuju terhadap peran media sosial sebagai alternatif SGD berbasis online untuk lebih menikmati topi diskusi. Pernyataan ke-18 menunjukkan bahwa lebih dari setengah persen responden menyatakan sikap setuju bahwa SGD berbasis media sosial dapat membantu mereka mengenal kelompok diskusi dengan baik.

Tabel 8 menunjukkan hasil analisis terhadap kategori penilaian sikap mahasiswa mengenai persepsi responden terhadap SGD berbasis media sosial.Kategori ini termuat pada pernyataan di dalam kuesioner nomor 20 - 26.Pada kategori ini, pernyataan diukur menggunakan reverse question, dimana penilaian diurut dari poin terbesar ke poin terkecil. Jawaban sangat setuju diberikan nilai $=1$, setuju $=2$, tidak setuju $=4$. Pada pernyataan ke-20, terdapat 55 orang $(57,3 \%)$ yang tidak setuju dan 1 orang $(1,0 \%)$ yang sangat tidak setuju pada pernyataan bahwa SGD berbasis media sosial menyebabkan responden merasa kurang termotivasi untuk terlibat dalam diskusi. Pada pernyataan ke-21, persentase dan jumlah yang menyatakan setuju dan sangat setuju sedikit lebih banyak daripada yang tidak setuju dan sangat tidak setuju. Terdapat 49 orang (51\%) yang setuju bahwa responden merasa kurang puas jika diskusi dilakukan melalui media sosial, karena tidak dapat melakukan diskusi secara langsung. Namun, 41 orang lainnya $(42,7 \%)$ menyatakan tidak setuju dengan hal tersebut. Pada pernyataan ke-22, 70 orang (72,9\%) dari 96 total sampel menyatakan tidak setuju mengenai perasaan tidak dihargai setelah mengikuti diskusi melalui media sosial. Pada pernyataan ke-23, terdapat 55 orang $(57,3 \%)$ menyatakan tidak setuju jika dalam diskusi responden akan merasa kecewa jika ide/gagasan yang disampaikan tidak digunakan. Pada pernyataan ke-24, terdapat 55 orang $(57,3 \%)$ tidak setuju dan 4 orang $(4,2 \%)$ sangat tidak setuju jika responden malas terlibat diskusi dengan metode SGD berbasis media sosial. Pada pernyataan ke-25, ada 74 orang $(77,1 \%)$ yang tidak setuju terhadap pernyataan bahwa mereka terlalu malu untuk melakukan SGD berbasis media sosial. Pada pernyataan terakhir, terdapat 48 orang (50\%) yang tidak setuju bahwa mereka terlalu bosan untuk melakukan SGD berbasis media sosial.

\section{DISKUSI}

Penelitian ini berusaha mempelajari gambaran mengenai sikap mahasiswa terhadap peran media sosial sebagai alternatif SGD secara online dengan menggunakan kuesioner yang merupakan adaptasi dari kuesioner pada penelitian sebelumnya. Dilakukan uji konsistensi internal pada kuesioner untuk memastikan relibialitas kuesioner dalam 
menggambarkan sikap mahasiswa yang diukur melalui empat jawaban, berupa sangat tidak setuju, tidak setuju, setuju, dan sangat setuju. Setiap pernyataan memiliki skor masing-masing yang dapat membantu interpretasi hasil penelitian.

Penelitian ini didominasi oleh perempuan dengan mayoritas berusia 21 tahun. Hasil yang didapatkan pada penelitian ini sesuai dengan studi yang dilakukan oleh Fitri dan Chairoel pada tahun 2019 mengenai tingkat konsumsi media sosial berdasarkan gender terhadap prestasi akademik. Penelitian ini menunjukkan bahwa perempuan memiliki frekuensi lebih besar berkaitan dengan penggunaan media sosial dibandingkan laki-laki. Selain itu, penelitian sebelumnya juga menunjukkan hasil serupa dengan hasil penelitian ini yang menunjukkan bahwa kelompok usia 21 tahun merupakan usia dengan jumlah terbanyak sebagai pengguna media sosial karena merupakan usia produktif dengan tingkat aktivitas sehari-hari yang cenderung tinggi. ${ }^{7}$

Sementara itu, berdasarkan analisa mengenai media sosial yang paling sering digunakan, media sosial LINE menjadi media sosial yang paling banyak digunakan oleh responden untuk melakukan berbagai fungsi, seperti komunikasi dan berbagai informasi. Hasil temuan tersebut sesuai dengan penelitian sebelumnya yang menunjukkan bahwa popularitas LINE di kalangan mahasiswa menempati urutan pertama sebagai media sosial yang membantu dalam pencarian dan berbagai informasi. ${ }^{8}$

Tingkat pengetahuan mengenai peran dan manfaat media sosial pada responden penelitian ini termasuk dalam klasifikasi baik, dengan lebih dari 50\% responden dapat dan mampu memahami peran serta manfaat media sosial. Temuan ini tentu menunjukkan kemampuan responden untuk menggunakan media sosial secara bijak dan sesuai kebutuhan. Hasil penelitian ini sesuai dengan penelitian sebelumnya dengan persentase pengetahuan yang baik lebih tinggi daripada penelitian sebelumnya. ${ }^{9}$

Penelitian ini berusaha memberikan gambaran mengenai sikap mahasiswa terhadap SGD berbasis media sosial yang diukur melalui empat komponen kategori pernyataan. SGD berbasis media sosial dapat mempermudah mahasiswa untuk berbagai ide/gagasan, mempermudah dalam berbagai tugas diskusi, membantu dalam mengambil keputusan diskusi, memudahkan dalam membantu teman lain untuk memahami materi diskusi, dan meningkatkan motivasi keterlibatan mahasisa untuk berdiskusi. Hasil ini sesuai dengan penelitian sebelumnya yang menjelaskan bahwa mahasiswa dapat membantu mahasiswa lainnya untuk belajar dan memahami topik diskusi dengan berbagai video di media sosial ketika SGD yang tentunya berhubungan dengan topik yang tidak dimengerti sebelum membantu secara langsung dengan mengajarkan mereka atau menjawab pertanyaan mahasiswa lain. Selain itu, pada kategori mengenai tingkat mahasiswa belajar melalui SGD berbasis media sosial, didapatkan hasil berupa meningkatkan kualitas diskusi, memudahkan proses belajar dan diskusi, memudahkan dan meningkatkan informasi yang diperoleh, meningkatkan kebiasaan belajar dan memudahkan dalam mengorganisasi hasil diskusi dengan baik. ${ }^{10}$

Peran media sosial sebagai alternatif SGD berbasis online menyebabkan diskusi menjadi lebih praktis dan menyenangkan untuk mahasiswa. Aspek seperti lebih menikmati diskusi, merasa lebih dihargai dalam forum diskusi, mempermudah individu untuk mengetahui teman diskusi, dan merasa menjadi bagian dari kelompok merupakan beberapa aspek yang dapat dilakukan melalui SGD berbasis media sosial. Hasil tersebut sesuai dengan penelitian Town pada tahun 2000 bahwa SGD dapat membantu mahasiswa untuk menjadi bagian dari kelompok diskusi dengan lebih baik. ${ }^{10,11}$

Sikap setuju yang ditunjukkan melalui penelitian ini memberikan gambaran berupa peningkatan keterlibatan dan partisipasi mahasiswa dalam mengikuti diskusi jika dilakukan SGD berbasis media sosial. Hal tersebut disebabkan karena SGD dengan media sosial diraskan akan lebih praktis dan efisien secara waktu. Hasil tersebut juga serupa dengan teori yang dikemukakan Flynn dan Faso yakni SGD merupakan cara yang efektif untuk meningkatkan keterlibatan mahasiswa dalam berdiskusi. ${ }^{12}$ Selain menjadi cara yang efektif, hasil penelitian ini juga sesuai dengan penelitian sebelumnya bahwa peranan media sosial dalam melaksanakan SGD juga efektif untuk meningkatkan prestasi belajar untuk seluruh kelompok usia. ${ }^{13}$ Persepsi positif terhadap peran media sosial sebagai alternatif SGD pada penelitian ini sesuai dengan penelitian sebelumnya yang dilakukan oleh Assegaf pada tahun 2017 mengenai persepsi positif penggunaan media sosial sebagai media diskusi untuk mendapatkan lebih banyak informasi. ${ }^{14}$

Penelitian ini menunjukkan hasil sikap positif responden terhadap SGD berbasis media sosial berdasarkan sikap mahasiswa terhadap SGD dengan media sosial, berapa banyak informasi yang didapat, tingkat kepuasan belajar dan diskusi melalui SGD berbasis media sosial dan persepsi mahasiswa mengenai SGD berbasis media sosial. Adapun keterbatasan pada penelitian ini adalah tidak dapat menunjukkan sikap mahasiswa pada program belajar lainnya selain SGD. Alasannya 
adalah terdapat perbedaan konteks belajar, latar belakang, dan responden. Hal tersebut juga dapat memengaruhi cara responden belajar atau berdiskusi terhadap materi yang berbeda, sehingga jika penelitian ini diplikasikan pada program belajar yang lain, hasilnya dapat berbeda. Keterbatasan lainnya adalah jumlah sampel yang terbatas dan pada cakupan yang kecil. Oleh karena itu, maka diperlukan penelitian lebih lanjut dengan sampel yang lebih besar dan pengukuran terhadap variabel cofounding yang mempengaruhi sikap mahasiswa.

\section{SIMPULAN}

Berdasarkan hasil penelitian mengenai sikap mahasiswa PSSKPD angkatan 2016 Fakultas Kedokteran Universitas Udayana terhadap peran media sosial sebagai alternative SGD secara online diperoleh simpulan bahwa media sosial yang paling sering digunakan adalah media sosial LINE. SGD berbasis media sosial dapat mempermudah mahasiswa dalam berbagai tugas diskusi, membantu dalam mengambil keputusan diskusi, memudahkan dalam membantu teman lain untuk memahami materi diskusi, dan meningkatkan motivasi keterlibatan mahasiswa untuk berdiskusi. Penelitian ini menunjukkan hasil sikap positif responden terhadap SGD berbasis media sosial.

\section{DAFTAR PUSTAKA}

1. Engeström Y. Expansive Learning at Work: Toward an activity theoretical reconceptualization. Journal of Education and Work. 2001;14(1):133-156.

2. Masters K, Ellaway R, Topps D, Archibald D, Hogue R. Mobile technologies in medical education: AMEE Guide No. 105. Medical Teacher. 2016;38(6):537-549.
3. Means B. Evaluation of evidence-based practices in online learning. Washington, D.C.: U.S. Dept. of Education, Office of Planning, Evaluation and Policy Development, Policy and Program Studies Service; 2009.

4. Kaplan A, Haenlein M. Users of the world, unite! The challenges and opportunities of Social Media. Business Horizons. 2010;53(1):59-68.

5. Silaban L. Students Attitudes Toward Small Group Discussion in the Academic Reading Class [Undergraduate]. Universitas Kristen Satya Wacana; 2016.

6. Yanse S. Student Perceptions On The Use Of Group Discussion And Their Engagement In The Speaking Sessions Of Cls I. [Undergraduate]. Student Perceptions On The Use Of Group Discussion And Their Engagement In The Speaking Sessions Of Cls I.; 2016.

7. Eka Yan Fitri M, Chairoel L. Penggunaan Media Sosial Berdasarkan Gender Terhadap Prestasi Belajar Mahasiswa. Jurnal Benefita. 2019;1(1):162.

8. Supratman L. Penggunaan Media Sosial oleh Digital Native. Jurnal Ilmu Komunikasi. 2018;15(1).

9. Anurgah Y. Pengaruh Iklan Politik Mars Perindo Di Televisi Terhadap Citra Politik Hary Tanoesoedibjo (Analisis Regresi Linear Sederhana) pada Pemilih Pemula di Kecamatan Depok, Sleman, DIY [Undergraduate]. UIN Sunan Kalijaga.; 2017.

10. Towns M, Kreke K, Fields A. An Action Research Project: Student Perspectives on Small-Group Learning in Chemistry. Journal of Chemical Education. 2000;77(1):111.

11. Joewono M,Karmaya INM, Wirata G, Yuliana, Widianti IGA, Wardana ING. Drawing method can improve musculoskeletal anatomy comprehension in medical faculty student. Anatomy and Cell Biology. 2018;51(1):14-18. DOI: https://doi.org/10.5115/acb.2018.51.1.14

12. Flynn E, La Faso J. Group discussion as learning process. New York: Paulist Press; 1972.

13. Eka Yan Fitri M, Chairoel L. Penggunaan Media Sosial Berdasarkan Gender Terhadap Prestasi Belajar Mahasiswa. Jurnal Benefita. 2019;1(1):162.

14. Assegaff S. Evaluasi Pemanfaatan Media Sosial sebagai Sarana Knowledge Sharing. Jurnal Manajemen Teknologi. 2017;16(3):271-293

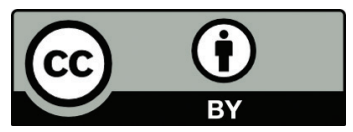

This work is licensed under a Creative Commons Attribution 